senior lecturer in the department of women and gender studies at Makerere University, is the executive director of the Centre for
Basic Research in Kampala and publishes on the politics of gender. Karuti Kanyinga is based at the workshop's host institution, and he has published numerous analyses of Kenya's power-sharing agreement and land reforms.

\title{
Title VI and Fulbright-Hays Cuts Impact Social Science Research
}

\author{
Brooks Marmon, Program Assistant, APSA International and External Relations
}

The APSA discovered just before going to press that the Fulbright-Hays Doctoral Dissertation Research Abroad (DDRA) Program, funded by the U.S. Department of Education, has been cancelled for FY 2011. From the inception of the awards in 1965 through 1994, 13\% of all Fulbright-Hays fellowships supported students of political science or economics. In FY 2010, at least ten doctoral political science students received DDRA funding for work in locations ranging from Brazil to Burma. The following article provides further background and highlights some specific research projects DDRA funding has enabled in Africa.

When this article was written, it was hoped that in a worst-case scenario, the FY 2011 budget passed by Congress would result in a smaller overall number of awards. Unfortunately, the funding constraints discussed here have been fully realized, causing this year's program to be cancelled entirely. The piece remains in its original form, in the hope that it poignantly illustrates the value of DDRA funding and helps make the case for its restoration in the FY 2012 congressional budget. The APSA continues to work with several partners, including the National Humanities Alliance and the Coalition for International Education, to reinstate this valuable resource for the social science scholarship of our nation's emerging academics.

A $s$ of this writing, funding for programs within the Department of Education funded by Title VI of the Higher Education Act and the FulbrightHays Act face cuts of $40 \%$. Title VI supports over 100 national resource centers at public and private universities engaged in area and language studies, while the Fulbright-Hays Act primarily supports doctoral dissertation research abroad. As a member of the Coalition for International Education and the National Humanities Alliance, the APSA is working to restore these funds, which play a critical role in promoting U.S. global competence.

One striking illustration of the value of Title VI and Fulbright-Hays support for political science research can be found in the work of emerging scholars funded by these programs. An examination of the professional biographies of the U.S. graduate students applying to our annual Africa workshop series (supported by the Andrew W. Mellon Foundation) highlights the importance of this funding.

The APSA received approximately 25 applications for the 2011 Africa workshop from U.S. graduate students (mostly political scientists, but also representing several other social science disciplines) competing for three openings in the workshop to be held at the University of Nairobi in Kenya. Each year, the impressive array of applicants furnishes a wide set of credentials. The typical candidate has significant experience in Africa and knowledge of one of the continent's languages, such as Portuguese, Arabic, Swahili, Setswana, or Yoruba, many of which are considered vital to U.S. national security interests. The U.S. Department of Education facilitated the experience of many of these doctoral students in Africa through Foreign Language and Area Studies (FLAS) Fellowships-a major component of Title VI funding and/or Fulbright-Hays Doctoral Dissertation Research Abroad (DDRA) Fellowships. Private foundations often focus their support toward more senior faculty, so these grants have played an invaluable role in allowing a younger generation of scholars to develop a solid base for their early research. With the acquisition of the language skills needed to conduct research abroad courtesy of a FLAS Fellowship, the Fulbright-Hays DDRA funding allows graduate students to effectively apply their training in the field.

Megan Hershey, a doctoral candidate in political science at Indiana University and a 2011 APSA Africa workshop applicant, received support from both programs. She began study of Swahili in the summer of 2005 on an FLAS-funded program, further developed her knowledge of the language over the course of the 2006-07 academic year, and then visited Kenya with DDRA funding. She observes, "FLAS funding prepared me with the language skills necessary to conduct intensive qualitative field work in Kenya and the Fulbright-Hays made that field work possible." Hershey's dissertation, "NGOs and Community Participation in Kenya's Fight against HIV/AIDS," explores the role of community-based NGOs that receive significant amounts of international funding.
Her Fulbright-Hays funding allowed her to spend almost a year interviewing staff and observing operations at several HIV prevention centers in Kenya. As Hershey states, she would not have been able to "collect impassioned views of the aid system from youth living in Nairobi's slums or conduct detailed observations of local civil society organizations," without this valuable support.

Hershey's dissertation deepens our understanding of the strategic political and social interactions between diverse groups of civil society actors and suggests that a numbersbased approach to international development has gained currency at the expense of more meaningful community participation. She has received several internal grants from Indiana University, but institutional funding is rarely able to facilitate insights as extensive as those derived from Title VI-funded language training and the sustained field experience of a Fulbright-Hays Fellow. Hershey believes that her graduate career "would be far less interesting" had she not received this federal support, and that it would have been much more difficult "to produce valuable and interesting research that has practical policy implications for both the United States and Kenyan governments."

Steve Lichty, another 2011 applicant and a student of political science at the University of Florida, received FLAS language training in Arabic and Swahili. He subsequently secured Fulbright-Hays funding that allowed him to track eight cosmopolitan churches in Nairobi for his dissertation, "Between Pulpit 
and Pew: Religious Influence on Political Belief and Behavior in Kenya." This work, which investigates the intersection of religion and politics in Kenya, has important policy implications, as the 1998 U.S. embassy bombing in Nairobi, Kenya, was one of al-Qaeda's first major attacks on U.S. interests. The Kenyan government continues to play a key role in thwarting global terror and ensuring regional stability as a result of its strategic location bordering Somalia and the emerging state of South Sudan. Lichty's completed dissertation will give us unique and useful insights into the influence of the Kenyan church on political activism.

Janette Yarwood, a Ph.D. candidate in anthropology at the City University of New York, a 2011 applicant, and a recipient of both DDRA and FLAS funding, believes that "cuts to the Fulbright or FLAS programs will greatly impact the potential research subjects and geographic areas that a new generation of scholars could work on because of the time and cost involved in becoming language and area experts." These limitations would lead to a decline in the quality and utility of U.S. scholarship and may also reduce the number of American area experts, particularly those with crucial foreign language skills.

The benefits of this funding go beyond facilitating the development of skills and opportunities for international travel. Many of the Fellows are pursuing critical research on sensitive topics. As foreign nationals, they are often better situated to discuss delicate issues, given their distance from local communities. Nevertheless, there are real dangers in pursuing research in post-conflict nations, and the depth of resources in a DDRA grant provide a scholar with the means to securely pursue research in critical and controversial fields.

Shannon Walsh, a Ph.D. candidate in political science at Notre Dame and a 2010 workshop applicant, is writing a dissertation on "State Response to Violence against Women in Latin America." In 2007-o8 she was a FulbrightHays Fellow in Nicaragua, Costa Rica, and Guatemala. She says that "having the Fulbright-Hays was crucial for getting my work done, especially in dangerous countries where I needed to rely on private transportation." Cara Jones, a Ph.D. candidate in political science at the University of Florida and a 2011 workshop applicant, is researching ethnicity and rebel movements in the Great Lakes region of Central Africa for her dissertation, "Rebels and State Transformation: Organization, Strategy and Capacity in Africa's Great Lakes." This dangerous area saw millions die in the Democratic Republic of the Congo's recent civil war, was the site of a bloody genocide in Rwanda, and continues to experience vicious attacks by Joseph Kony's Lord's Resistance Army. As a Fulbright-Hays grantee, Jones was based in Burundi, a country that has maintained a strong UN presence after transitioning from a peacekeeping operation in 2006. Many university funding sources are sufficient to enable short-term travel to facilitate overseas research, but FulbrightHays funding (which averaged over \$38,0oo for each award in 2010) provides recipients a more substantial means to safely and efficiently engage in thorough research abroad by enabling the provision of secure housing, adequate transportation, and local guides.

The examples cited here illuminate only a handful of graduate students supported by
FLAS and Fulbright-Hays Fellowships. The Fulbright-Hays Act celebrates its semi-centennial this year. The past 50 years have seen a tremendous growth in area studies, which is increasingly necessary in a more globalized world. Courtesy of academic research, the U.S. public and policymakers today are much better informed of important trends and movements outside of our borders.

In recent years, the APSA has significantly increased its efforts to internationalize the profession. In 2004, the Association resolved that "a systematic engagement with non-American materials makes our discipline, our political understandings and our theories better." The APSA subsequently introduced new membership rates for political scientists in low- and middle-income countries, reduced foreign postage fees for journals, and increased support for scholars from non-OECD countries to attend Annual Meetings. In addition to our work in Africa, the APSA recently concluded projects with political scientists from India and Japan.

Building a stronger professional environment for political science and the promotion of scholarly research are two of the APSA's core goals. Any cuts to programs within the Title VI Act for Higher Education and the Fulbright-Hays Act present a set-back to the discipline and its scholarship. Those who will be most adversely impacted are our nation's graduate students, who benefit immensely from the training and experience these programs provide. If these cuts are enacted, the ability of doctoral candidates to engage in critical inquiry will be limited, and the strength of their intellectual foundations will be reduced.

\section{UPCOMING INTERNATIONAL CONFERENCES}
July 3-6
24th Annual Conference of the International Association for Conflict Management, Ceylan InterContinental, Istanbul, Turkey, http://www.bus.umich.edu/ConferenceFiles/IACM-Conference-2011-Istanbul/IACM\%202011\%20 Call\%2ofor\%2oSubmissions.pdf.

July 20-23

Aug 31-Sept 2

Sept 6-8

Sept 30-Oct 2

3rd Paris International Conference on Education, Economy and Society, Hotel Concorde La Fayette, Paris, France, http://www.education-conferences.org.

French Political Science Association 11th Biannual Conference: Comparing Legislatures, Strasbourg, France, http:// www.apsanet.org/content_71222.cfm?navID=603.

5th Global Conference: Fear, Horror, and Terror, Mansfield College, Oxford, UK, http://www.inter-disciplinary.net/ at-the-interface/evil/fear-horror-terror/

\footnotetext{
Atlantic Provinces Political Science Association 2011 Annual Meeting, Mount Allison University, Sackville, New Brunswick, Canada, http://appsa2011.wordpress.com/.
} 